Срђан Веселиновић

Гимназија

„Бора Станковић“, Ниш
$94(=411.16)(560)$

https://doi.org/10.18485/ai_lik.2020.6.9.6

Оригинални научни рад

\title{
УЛОГА РАБИНА \\ ИЗ ПЕРСПЕКТИВЕ ОСМАНСКОГ ЦАРСТВА
}

Велика популација Јевреја у Османском царству јавља се после декрета краљице Изабеле и краља Фердинанда (1492), тј. њиховог протеривања из Шпаније, након Реконквисиее, у време султана Бајазита II.

Јеврејска заједница, особена, јединствена, имала је строга правила свог функционисања, дефинисана традицијом и религијом. Таква крута правила морала су бити промењена у судару са правилима шеријата, исламском кодексу по којем је функционисало Османско царство, али и државе какву је замислио Мехмед Фатих (1451-1481).

Кључне речи: Јевреји, Османско царство, рабин, хахам баша, Цариград, Света Земља, Тора, Сефарди, Ашкенази.

\section{Јевреји и Османско царство}

До првог сусрет Јевреја са Османским царством долази непосредно по османском освајању Мале Азије. Али не у оним првим годинама после битке код Манцикерта (1071. године) већ знатно касније, након освајања егејског приобаља и већих градова, од тада већ посрнуле Византије, где Османлије налазе јеврејско становништво, тзв. Романойе. ${ }^{3}$

Јеврејско становништво, углавном трговци, али и занатлије, промену власти нису доживели тако трагично, због незавидног положаја и третмана „грађана другог реда“ од стране византијских власти. Сам положај Јевреја, након римског протеривања из Јудеје, после Бар-Кохбине буне (син

3 D. Tanasković, Jevreji u osmanskoj ekumeni, Istoci i utoci, Sećanje na Slavoljuba Đinđića, Beograd, 2009, 94. 
звезде) 135. године, у расејању, био је различит. Хришћани нису тако благонаклоно гледали на њих, окривљујући их за Христове патње и Његову мученичку смрт, као и неприхватање Његовог учења. Трпели су их на својој територији, али без неких великих права. Штавише, знали су да оптуже Јевреје и за нека зла која су их погађала.

Појавом Арабљана, тј. ислама и арапског освајања медитеранског приобаља, драстично се поправио положај Јевреја на тим, до скора, византијским, хришћанским територијама. Јер их Арапи, а касније и Османлије нису доживљавали као реметилачки фактор, већ као веома користан народ. Благ однос према Јеврејима, уз одређене финансијске клаузуле, долази још из периода ширења ислама на арабљанском полуострву, тачније из документа познатог као „уговор из Неџрана“" 4 Тим уговором регулисана су сва права и обавезе немуслиманског живља у оквиру Дар ел ислама (куће ислама). Слично је било и у Шпанији, у краљевству Визигота, које је од 711. године под Арабљанима. Због сазнања о положају својих сународника под муслиманском влашћу, османска освајања византијских територија, а онде где су живели Јевреји, дочекана су благонаклоно. Што се, на крају, и испоставило као тачно.

До већег прилива јеврејског становништва у Османско

4 Пророк Мухамед је 630. године хришћанима из јеменског града Неџрана наметнуо уговор који је обухватао обостране обавезе, и хришћана као поданика, али и муслимана као господара: „Алахова

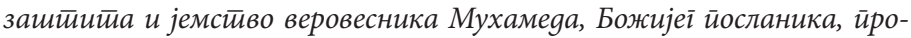
сиииру се наg Неираном и юеіовом околином, наg юиховим добрима, личностиима, вршенем верских обреgа, свима одсуйнима и иррисуйнима, юиховим йородицама, светиилиштиима и свему шито се, велико или мало било, налази у юиховом йосеgу. Нијеgан ейиской неће битии удаљен из своје еитскойије, нијеgан монах из своі манастиира, нијеgан свешитеник из своје йарохије. Неће их ирритискиватии никакво йонижене, као ни крв неке ирретххонне осветее. Неће бити скуйлани, нитии йлаћатии десетиак. Нијеgна војска неће йовреgитии юихово итло. Каg неки оg юих зайражи измирене своі gуїа, йоравнане ће сами међусобно извриитии. Они неће битии ни итлачитетьи ни йойлачени. Ако неки оg

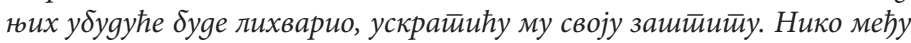

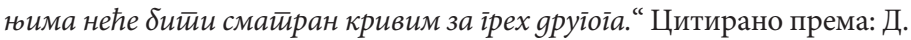
Танасковић, Ислам: gоіма и живот̄, Београд, 2008, 288. 
царство долази након шпанске, тј. хришћанске реконквисте Иберијског полуострва, после декрета шпанске краљевске породице (1492. године) и протеривања Јевреја и Марана (погрдан назив за хришћане, бивше Јевреје - дословно значи свиње) из њиховог краљевства. Тада је са Иберијског полуострва протерано око 300000 Јевреја. Познавајући рад и дело јеврејског живља, османски султан Бајазит II прихвата оберучке ове прогнанике и изговара ону чувену реченицу: „Како он може бити муgар влаgар каg је осиромашио

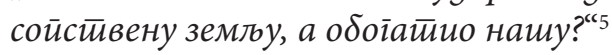

Овај декрет краља Фердинанда и краљице Изабеле, одвео је Јевреје у ново расејање. Једни су се одселили у друге европске, хришћанске земље, али добар део њих је отишао у Османско царство, због прича о положају њихових сународника тамо, али и позивима истих да дођу и уживају у слободи коју им даје Султан. Један од таквих позива стигао је од историчара Елијаха Капсалија, ${ }^{6}$ Романойа са Крита.

\section{Функционисање јеврејске заједнице}

Прве веће јеврејске заједнице, у Османском царству, забележене су у самом Цариграду, али и у Измиру, Једрену, Бурси, Солуну, црноморском приморју, другим градовима Пелопонеза, Леванта, Египта ${ }^{7}$ али и градовима данашње Србије, Нишу, Београду, Новом брду...

Насељавање Јевреја у неко место доносило је, по њиховој традицији, и формирање јеврејских општина, зидање синагога/молитвених домова, нарочито у време Селима II $(1566-1574){ }^{8}$

Ради лакше контроле становништва, па и јеврејског, Османлије су практиковале да одреде старешине које би

5 Д. Џ. Голдберг, Џ. Д. Рејнер, Јевреји: исӣорија и релиіија, Беоїраg, 2003, 126.

6 D. Tanasković, nav. delo, 95.

7 С. Калдерон, др. Ј. Леви, Исйорија јеврејской нароgа, Београд, 1935, 7.

8 R. Porter, S. Harel-Hoshen, Odyssey of the Exiles - The Sephardi Jews 1492-1992, 105. 
управљале неком заједницом и све те старешине би директно одговарале Цариграду. Тако је за време Селима I (1517) за вођу египатских Сефарда одређена титула наїиgа и то је трајало наредних 200 година.

Широм Османске империје ницала су јеврејска насеља, па и читави градови (ово је више било уобичајено у Светој Земљи, или како су је Јевреји звали Ереи Израел). У саму организацију тих насеља и градова Османлије се нису мешале, све су то препустили самим Јеврејима којима то и није било тако тешко, јер су ту своју организацију само пресликали из оних места одакле су дошли.

Основа самоуправе била је конгрегација-заједница (kahal), мања или већа група људи, породица, окупљена око једне синагоге. Њихова веза била је трајна. Оваквом заједницом су управљали и верски и световни главари, с подељеним надлежностима. Средишња установа овакве заједнице била је основна верска школа (Talmud Torah), а у већим и имућнијим заједницама су осниване и средње школе (yeshivah). Верски поглавар био је рабин. Тамо где је било више оваквих заједница формиране су заједничке градске општине (kehillah). Овакве општине су репрезентовале Јевреје пред локалним османским властима. Без обзира на то колико заједница је имало једно место, увек се тежило формирању надконгрегацијске јеврејске општине. Изузетно су могле постојати и две (као у Цариграду), па и више општина у зависности од реалних услова и ситуације. ${ }^{39}$ Податак извесног Јеврејина који је посетио Јерусалим око 1552. говори да је тамо пронашао четири скупине Јевреја: ашкеназе - Јевреје из Немачке; мустиарабе - припаднике локалне јеврејске општине; маіре$\delta u \bar{u} e$ - досељенике из северне Африке и много сефарgа који су представљали најутицајнију јеврејску општину. Набројао је преко 300 породица. Тамо где је формиран већи број општина много више им је одговарало да се повремено формира нека делегација или комитет, него ли да трајно концентришу моћ и ауторитет у рукама једног тела или појединца. Плашили су се злоупотребе или корупције. 


\section{Верска организација Јевреја у Османском царству}

Верска организација једне етничко-конфесионалне мањине у некој држави, пре свега, зависила је од закона, боље речено верских ставова доминантне религије према другима. Што се тиче самог ислама, он је верске мањине делио на „нароgе книіе“ (ap. ahlal-kitab) и на йаїане. Ови други нису имали никаква права, тако да су могли да бирају између смрти и примања ислама. Што се пак народа књиге тиче, њихова права су утврђена уговором из Неџрана, чиме су они постали „ийићенищи“ (ар. dimma, тур. zimma) ислама, уз поштовање одређених верско-законских мерила и плаћање пореза. Тако им је живот у Османском царству био условљен овим. Толерантнији став долази од Мехмеда Фатиха и његовог схватања ислама након освајања Цариграда (1453). Он је на себе гледао као на легитимног наследника византијског царства, где ислам нема пресудан значај. Заступао је хетеродоксна учења у оквирима ислама. ${ }^{9}$ Такав дух се пренео и на његове наследнике, мада, положај немуслимана је варирао током периода рата и мира.

Заједно са Грцима, Јерменима и муслиманима чинили су један од четири главна милета у Османском царству (милети - систем верских заједница у Царству са широким степеном аутономије). ${ }^{10}$

Треба рећи и то да је прва штампарија у Цариграду отворена 1493. године од стране Јевреја. Два брата, сефарgа, Давид и Самуел Бен Нахмиас су добили дозволу за рад под условом да не штампају књиге на арапском језику. ${ }^{11}$

Охрабрени повратком у Свету Земљу, Јевреји су се још јаче окретали својој вери. Веома брзо је економски јак Сафед прерастао у духовни центар Јевреја у Османском царству, па и шире. Тамо се у XVI веку доселило доста шпанских Сефарga

9 Е. Миљковић, Мехмеg II Освајач и йитиаюа верске йолераниије у османској gржави, Свети цар Константин и хришћанство: Међународни научни скуп поводом 1700. годишњице Миланског едикта 31. мај - 2. јун 2013. Том I/ уредник Драгиша Бојовић - Ниш: Центар за црквене студије, Ниш, 2013, 648.

10 Е. Миљковић, нав. дело, 647.

11 D. Tanasković, nav. delo, 97. 
и Марана, а придружило им се пуно следбеника мистицизма. Развиле су се многе јешиве и друштва која су изучавала Тору (Свето Писмо). Све то било је изводљиво захваљујући обилатој новчаној подршци богатих Јевреја расутих по целој Европи, али и добростојећих Јевреја из Царства, нарочито из Цариграда. Податак неког Јеврејина, досељеника из Чешке, из 1563. године говори да није могао да се начуди да у Сафеду постоји 18 јешива, 21 синагога, бесплатна јавна школа са 400 ученика који су изучавали Библију и Талмуg, као и близу 300 рабина. ${ }^{12}$

Због тога и не чуди што је управо одатле, из Сафеда, покушано са обновом врховног представништва нације, синеgрионом. Покретач ове идеје био је рабин Јаков Бирав. Он је у симболичном обреду рукойолаїағь видео пут ка избављењу и обнављању синеgриона, а и појави Месије. То је касније довело до навале лажних Месија и многих разочарања, попут оног са Сабетај Зевијем, ${ }^{13}$ чему је кумовало и Хааријево учење. Мислилац који је у корену изменио то јеврејско мистичко учење био је Исак Лури Ашкенази, а народ га је прозвао „Светии Лав“ (хебр. Haarihakadosh). Умро је са 37 година (1572), али је оставио велики траг који су следили многи. Пошто су његови следбеници углавном били они који су преживели прогон и уточиште нашли у османској држави, тежили су ка томе да се коначно избаве и окончају са овоземаљским мукама. Основу за то су нашли у Хааријевој мистичној кабали која је била прожета мистичним и месијанским учењем. ${ }^{14}$

Међутим, учење Бирава није условило само појаву месијанских покрета, већ је директно утицало и на неке његове ученике који су написали чувена дела, попут Јосефа Кароа (1488-1575), шпанског Јеврејина који се 1525. доселио у Сафед и 1552. издао своје чувено дело Шулхан арух (Посииављен сйо). То је био зборник јеврејских закона и подробан верски кодекс, који је оставио велики утицај на живот Јевреја широм света. Међутим, јерусалимски мислиоци су се успротивили овој идеји Бирава за обнову синедриона, тако да је та ствар пропала. ${ }^{15}$

\footnotetext{
12 Š. Etinger, nav. delo, 264.

13 Р. Мантран, Историја османског царства, Београд, 2002, 407.

14 Р. Мантран, нав. дело, 267.

15 Исто, 265.
} 
У Сафеду је живео и радио песник Шломо Алкабец, творац литургијске химне „Леха gођи“, којом се до дана данашњег поздравља долазак Суботе у свим синагогама. ${ }^{16}$

Верско пробуђење у овом галилејском граду било је толико велико, да се Реч Божија проучавала свуда, у сваком дому и до дубоко у ноћ. ${ }^{17}$

Свака јеврејска конгрегација имала је своју сопствену организацију, поготово у великим градовима. Иако је свака конгрегација деловала посебно, у Солуну је постојало једно централно верско тело, које је бринуло о теолошким стварима marbitzei Torah (у преводу пропагатори Торе). Поред овог тела деловао је и betdin (суд рабина), и он је имао ингеренције над свим конгрегацијама у граду. Суд је заседао у синагогама и није имао физичког значења и надлежности су му зависиле од договора са локалним кадијом и утицајем самих судија. Јевреји су се веома често обраћали муслиманским судовима, без обзира на ком пољу су претходно биле донесене пресуде, и неретко су обарали одлуке рабинског суда. ${ }^{18}$

Солун као центар у Румелији, са толиким бројем Јевреја свих конгрегација, био је чувен и по Великој Талмуg Тори, школи отвореној за сву јеврејску децу. ${ }^{19}$

Несумњиво је да су новопридошли Јевреји, нарочито Cебарgu (не треба потценити Ашкеназе, али је утицај првих био знатно већи), извршили велики утицај на домицијалне Јевреје и наметнули се својим образовањем и предузимљивошћу. Њиховим доласком, Османско царство у XVI и XVII веку постаје средиште учених Јевреја. Један део њих је своје корене изводио од Давида до њихових времена, те су своје обичаје и говор сматрали изворним. Већина јеврејских верских и других књига штампано је управо овде. А писци су углавном били Сефарди, док су рабини из Италије и северне Африке били у мањини. Списак ових схоларика је импозантан. $^{20}$

\begin{tabular}{ll}
\hline \hline 16 & Исто. \\
17 & Исто. \\
18 & R. Porter, nav. delo, 102. \\
19 & Исто, 106. \\
20 & Исто, 118.
\end{tabular}


Град Сафед је постао и центар Кабале. Ту је написано и чувено дело, из ове етичке литературе, рабина Елијаха де Видаса „Reshit Hokhmah” (Прво установљено). Праћено низом правних и етичких радова, као и писања рабина Мозеса Кордовера и рабина Јосифа Кара. И ово учење и литература су, поред Хаарија, послужили Сабетејцима као инспирација. ${ }^{21}$

\section{Рабин и Хахам баша}

Да бисмо у потпуности схватили шта је рабин, како Јевреји доживљавају његову улогу и положај у верском животу, па и самој заједници, морамо, пре свега, знати од кад датира та титула и како је било у почетку, док је функционисала сама држава Израел.

Сама реч рабин долази из библијског хебрејског rav и дословно значи велики, а у свом литерарном хебрејском значи господар, као супротност робу. ${ }^{22}$ У почетку су рабини били нешто сасвим друго у односу на данас. Рабин је био онај који је проучавао Тору и који је познавао усмени закон, док данашњу функцију, улогу, рабина налазимо тек од средњег века, у периоду од X до XII века. Тада, међу Сефардима, то постаје дословно оно што и у хришћанству свештеник, проповедник. ${ }^{23}$ У јеврејским заједницама ван Erez Israel-a (државе Израел) рабин је, у јеврејским заједницама, преузимао улогу вође, судије, верског поглавара. Свака јеврејска општина имала је свог рабина, који је имао ингеренције искључиво у повереној му заједници.

У јеврејској традицији није постојала институција, функција врховног рабина, али су Османлије, тежећи бољој организацији, бољој контроли свих, а пре свега због уредног убирања пореза, захтевали и увели функцију врховног рабина (тур. hahambaşi хебр. ravha-kolel). ${ }^{24}$ Први је на

21 R. Porter, nav. delo, 118.

22 Encyclopedia Judaica, 1545.

23 Исто 1546.

24 D. Tanasković, nav. delo, 99. 
то место ступио Мозес Капсали (1420-1495?), Романиот из Цариграда, који је уживао Султанов углед поред великог муфтије и цариградског патријарха. То поверење код Фатиха стекао је својим поштењем, мудрошћу, али и редовним сакупљањем пореза међу Јеврејима. Имао је неограничену власт у унутрашњим стварима јеврејске заједнице. Под његовим утицајем многи су се населили у Османско царство, али је такође и избавио многе из ропства пирата, када би ухватили неког од њих. Након смрти Капсалија долази Елијах Мизрахи, такође Романиот... ${ }^{25}$

У свим већим јеврејским заједницама унутар Османског царства постојао је rav kolel кога је бирала сама заједница, а не Царство.

Како би задржали ову привилегију рабина, Јевреји су за титулу хахам баше давали годишњи порез зван rav aqshezi (бела кованица, сребрни новац). Овај порез се плаћао и дуго после XVII века, дуго након што је титула хахам баше, као врховног рабина, била укинута.

Хахам баши је поред сакупљања пореза, вршио улогу врховног судије међу Јеврејима, био вођа и учитељ Јешива, а међу самим Јеврејима не ретко називан је и reish mata, што би у преводу са арамејског било „поглавар града“. ${ }^{26}$

У Измиру су, за разлику од других градова, њих двојица вршили ову функцију. Један је био задужен за цивилни закон, а други верска питања, а обојица су називана ha-rav ha-gadol. Имали су и своје помоћнике morei zedek. У овом граду је забележено да су њих четворица вршила ову функцију врховног рабина истовремено.

Царство је 1834. године у Цариграду установило канцеларију хахам баше. Ту функцију могао је да обавља само становник Османског царства и његова улога била је да управља свим рабинима у Царству (чак и оном у Јерусалиму). Сличне канцеларије отворене су у још неким већим градовима османске државе. Тачне дужности и права Хахам баше утврђене су законом из 1864. године. Хахам баши у Египту имао је само улогу верског вође. У Erez Israel-y врховни рабин звао се

25 Encyclopedia Judaica, 1547.

26 Исто, 1451. 
rishon le-Zion (први у Циону) и премда функционише од XVII века, функција је призната тек 1842. године, када је и преименована у hakham bashi Erez Israel. Хахам баши је 1874. године установљен и у Триполију и веома брзо је постало популарно те се широм целе северне Африке јављају титуле хахам баше. У Јемену су, рецимо, османске власти 1874. године поставиле Соломона Кареха за хахам башу као највећег световног и верског вођу. ${ }^{27}$

Институција, функција хахам баше у Османској држави трајала је колико и та држава. Укидањем Царства и проглашењем за републику Турску 29. октобра 1923. године рабини у Турској постају оно исто што и у свим другим државама, верски учитељи, свештеници у својим локалним јеврејским заједницама/општинама.

Положај самих Јевреја у великом Османском царству можемо посматрати само из угла званичне религије Царства, али и схватања вере Османлија и њихових султана, почев од Мехмеда Фатиха (1451-1481) који је, како наглашава Франц Бабингер, највећи познавалац личности Мехмеда Освајача, освајањем Цариграда 1453. године себе доживео као владара светског, а не верског царства. Ова чињеница давала је сасвим другу димензију погледа на остале конфесије у Царству, самим тим и њихов положај.

Оно што сигурно знамо је то да је, у периоду који смо обрадили, Јеврејима несумњиво било боље у Османском царству, него у хришћанској Европи. Прогони, пљачке, мучења, убијања, једном речју муке кроз које су пролазили Јевреји у западним земљама, натерале су их да пронађу безбедније место под небеским сводом. У том тренутку Османско царство представљало је „Рај на Земљи“ и престанак свих патњи, далеко од идеалног, али узевши све у обзир, итекако боље од услова у којима су живели у претходном периоду под хришћанским владарима.

27 Encyclopedia Judaica, 1452. 
Нова земља, уточиште, пружила је могућност расутој јеврејској популацији да се окупи на једном месту, у једној држави и настави да живи по својим обичајима и схватањима. Та могућност помогла им је да опстану у периоду кад им је било најтеже и када је један део Јевреја већ почео да напушта своје веровање, прелази на католичанство и полако губи свој јеврејски идентитет.

Дакле, чини се да су католички монарси Шпаније и Португалије, али и господари других делова Европе, учинили услугу Јеврејима протерујући их са своје територије. Османски владари су такође, без обзира на прихватање Јевреја ставили материјални интерес и интерес државе, а све у циљу даље експанзије свог царства, испред религије.

Такав начин живота био је далеко од идеалног, јер је положај Јевреја само у компаративном смислу, када упоређујемо живот под хришћанима и живот под муслиманима, био бољи. Међутим, сама чињеница да су тако масовно прешли на територију османских владара, као и то да су их виђенији Јевреји Османског царства позивали да се доселе ту, дају нам право да кажемо да је њихов живот међу муслиманима био итекако подношљивији, самим тим и бољи, од живота који су имали међу хришћанима.

Таква повољна ситуација за Јевреје потрајала је релативно кратко, а опет довољно дуго да су могли да се опораве, консолидују и сачекају промене и бољу атмосферу у другим деловима Европе и света. Предузимљиви и добро организовани, ситуацију у Османском царству која им није пружала прилику за просперитет, после XVII, а нарочито XVIII века, поново су изменили тако што су смер своје миграције са истока пребацили на запад.

Ситуација у Царству и став Османлија према Јеврејима и њиховој верској организацији, донео је доста промена у њиховом схватању, али то и није представљао неки проблем самим Јеврејима, јер су се веома брзо прилагодили оваквом схватању и функционисању свог верског вође.

Модерна Турска „вратила“ је улогу, положај рабина јеврејској заједници онакав какав је био у средњем веку, установљен од сефарда, где је свака заједница имала свог 
независног рабина који је деловао у складу са обичајима те заједнице и простора на којем је обитавала и функционисала. Свакако да је концепција Царства била јединствена, гледано и из перспективе религије, прецизније ислама и њиховог шеријата, али и из секуларног, државничког угла. Све то се одразило и на Јевреје и саму институцију рабина, где су за тренутак (пар векова), опробали функционисање неких традиционалних хришћанских деноминација, које функционишу по том принципу, централизованог управљања.

Уосталом, тако је функционисала и Српска православна црква, у Османском царству, од обнове патријаршије па све до њеног укидања (1557-1766).

\section{Извори и литература}

Голдберг Џ. Дејвид, Џон Д. Рејнер, Јевреји (истиорија и релиіија), Београд, Клио, 2003.

Encyclopedia Judaica, volume XVI, Jerusalem, Israel.

Калдерон Соломон, др. Јуда Леви, Исииорија јеврејскоі нароgа, Београд, 1955.

Мантран Робер, Истиорија Османскої иарстива, Београд, Клио, 2002. Миљковић Ема, Мехмеg II Освајач и йитиаға верске ииолераниије y османској gржави, Свети цар Константин и хришћанство: Међународни научни скуп поводом 1700 годишњице Миланског едикта 31. мај - 2. јун 2013. I том/ уредник Драгиша Бојовић - Ниш: Центар за црквене студије, Ниш, Пунта, 2013. Porter Ruth, Harel-Hoshen, The Sephard Jews 1492-1992, The Nahum

Goldmann Museum of the Jewish Diaspora, Tel Aviv, 1992.

Танасковић Дарко, Ислам: gоіма и живой, СКЗ, Београд, 2008.

Tanasković Darko, Jevreji u osmanskoj ekumeni, Istoci i utoci, Sećanje na Slavoljuba Đinđića, Beograd, Filološki fakultet, 2009. 


\section{SrđanVeselinović}

\section{THE ROLE OF THE RABBI FROM THE PERSPECTIVE OF THE OTTOMAN EMPIRE}

By the end of the 15th century, as peacefully as possible, many Jews lived in Western and Southern Europe, when their persecution began. Most were expelled from the Spain by the decree of Queen Isabella and King Ferdinand (1492).

They find refuge in the Ottoman Empire, where they are accepted by Sultan Bajazit II (1481-1512). This is where they get every freedom, that is. all that the sharia allowed. They stand out as good merchants, craftsmen, teachers, which has earned them a great reputation and affection for the Empire.

However, the Ottoman understanding of organization required the centralization of power, all of which was contrary to Jewish tradition and organization. So the institution, function, haham basha, of the supreme rabbi was established, which also united the function of leader.

The only thing the Ottomans demanded was that the subjects of the Empire be calm, collect their taxes regularly, and duly respond to every call and request of the state. All this is combined in the role of haham basha. This institution functioned for as long as the Empire lasted until October 29, 1923, when the Republic of Turkey was proclaimed. This was a unique case of the functioning of the Jewish community and the role of the rabbi. Although not specific to the Jewish tradition, they nevertheless obeyed the request of their new state, thereby further gaining the trust of the Ottomans.

Key Words: Jews, the Ottoman Empire, rabbi, haham basha, Constantinople, the Holy Land, Torah, Sephardim, Ashkenazi. 